\title{
Climate Change Impacts on Water Scarcity and Food Security in Tropical Environments: The Case of Caribbean Region
}

\author{
Abdelaziz A Gohar ${ }^{1,2 *}$ and Adrian Cashman ${ }^{1}$ \\ ${ }^{1}$ Centre for Resource Management and Environmental Studies, the University of West Indies, Barbados \\ ${ }^{2}$ Departments of Agricultural Economics and Extension, College of Agriculture, South Valley University, Egypt
}

Submission: July 04, 2017; Published: July 06, 2017

*Corresponding author: Abdelaziz A Gohar, Centre for Resource Management and Environmental Studies (CERMES), the University of West Indies, Barbados, Caribbean, Tel: +12464174512; Fax: +12464244204; Email: abdelaziz.gohar@cavehill.uwi.edu

\section{Abstract}

The potential impacts of climate change on water scarcity and food security are a major area of concern for researchers and policy makers around the world, especially in tropical regions. Tropical regions are highly vulnerable to climate change, which poses increased threats to water and food security. While precipitation is the major source of freshwater in tropical regions, the agricultural sector and food production are under threat due to the impact of climate change. Recent downscaled regional data using the Representative Connection Pathway (RCPs) emission scenarios on precipitation shows a trend of decreasing precipitation in some tropical regions and Small Island Developing States (SIDS) to the year 2100. The implication of this is that aquifer storage that used to meet the water demands of urban, agricultural, and environmental uses can be expected to be negatively affected. Increased water demand for urbanization, food production, and environmental sustainability calls for a better understanding of climate change impacts on water scarcity and food security. This is the key to implementing better adaptation and mitigation polices for climate change. Future research should focus on the connection and causality affects between water scarcity, food security, and their socioeconomic impacts in the context of adaptation and mitigation programs.

Keywords: Climate change; Water scarcity; Food security; RCPs; Adaption policy

Abbreviations: RCP: Representative Connection Pathway; SIDS: Small Island Developing State; ET: Evapo-tranpiration; IPCC: Intergovernmental Panel on Climate Change

\section{Mini Review}

The potential impact of climate change on water scarcity and food security poses increased challenges on water resources and for policymakers in tropical regions. Tropical regions are among the most vulnerable to the effects of climate change particularly with regard to water resources. At the same time these regions are also facing growing water demands from urbanization and agriculture due to growing populations and economic development. Tropical Small Island Developing States (SIDS), may experience decreased water supply along with growing water demand in the medium and long run [1]. Information from regional downscaled Representative Connection Pathway (RCPs) emission scenarios developed by IPCC 2014 show a general trend of declining precipitation, increasing up to 2100 [2]. The importance of precipitation as major source is associated with the high dependency many SIDS on their groundwater systems to meet the demand for water from different sectors.
Decreasing precipitation in tropical regions has been associated with increased temperatures. that could will drive increases in evapotran aspiration (ET) rates which has implications for the agricultural sector. In addition, groundwater recharge could sharply decline $[3,4]$. As a result of these factors, less water would be available over time to meet the growing demand of competing sectors. On the one hand, decreased precipitation will directly impact agricultural production and food security as crop yields are expected to decline [5,6]. On the other hand though, food producer could increase the use groundwater as a secondary source of irrigation and adopt irrigation technology such as drip irrigation and sprinkler irrigation etc. Given the fact that many islands are already experiencing overexploitation of their ground water resources, more efficient and sustainable adaptation and mitigation policies are required for future water management. However, 
introducing greater use of irrigation technologies, as adaptation policy for climate change, whilst promising in some respects, could still pose challenges. Recent research indicates that decreasing precipitation would be associated with declining rates of recharge to the aquifer systems [7].

This implies falling water tables and increases in pumping depths, which would increase the cost of pumping. The cost could include the capital cost of the systems installed, energy costs, and scarcity value of water. In recent years, increased efforts have been devoted to exploring the future trend and magnitude of climate change in different regions and sectors. The projection of changeability in climatic parameters such as precipitation is associated with high level of uncertainty over time and geography [8]. The majority of the projections are concentrated around the physical change in those climatic parameters such as precipitation and with less attention paid to the socioeconomic impact of projected climate change. The investigation of the socioeconomic impacts of climate change represents another challenge for researcher s given the fact that water demand and supply is heterogeneous in nature.

While all freshwater supply is ultimately from precipitation, the pathways and interactions that shape the transition of from rainfall to resource creates different qualities of water and availabilities. Water used for irrigation in agricultural is often different in quality and quantity from that used for domestic purposes. Tracking the added value of water improvement should be the corner stone of policy design and implementation particularly with respect to adaptation and mitigation to climate change. The economic efficiency and sustainability principles of allocating and utilizing this critical scarce resource for humanity and ecosystem should be recognized through more accurate economic valuation without overlooking the principle of equity.

In Small Islands Developing States, where the vulnerability to climate change is a major concern, water availability could be a major stressor particularly under the more severe climate scenarios. Noting that SIDS contribute little to global $\mathrm{CO}_{2}$ emission [9]. Recent projections of downscaled regional data for the Caribbean of the precipitation show significant declines in rainfall which will impact water availability, under the more severe RCP 8.5 emission scenario. This is illustrated in (Figure 1) for the Island of Barbados. Potential future water scarcity would have major economic consequences that would be unevenly distributed among different water users. Sectors with a greater ability to afford water such as tourism, industry, and commercial sectors have a better chance to maintain their water demand as compared to low value water users such as the agricultural sector. Under RCP 8.5 for example, lower value users such as agricultural and household users would shoulder the major consequences of the impact of climate change. Even, within a sector, the economic consequences of climate change would also be unevenly distributed among users. Recent research into the food producer-food consumer nexus have indicated that food consumers will bear the majority of the consequences in terms of less food available and higher food prices (Figure 2).

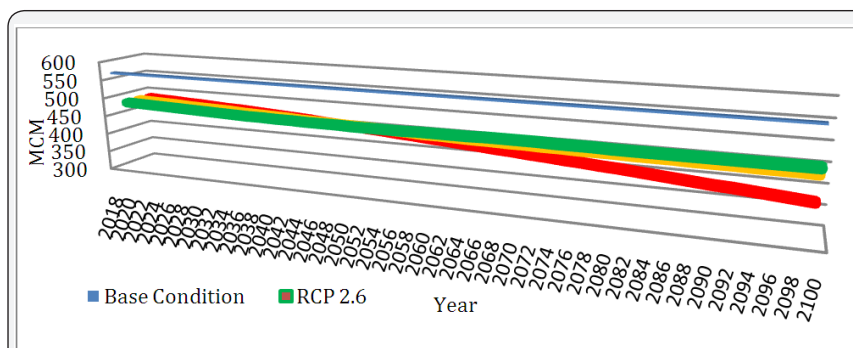

Figure 1: The projected total annual water availability from precipitation by Representative Connection Pathway (RCP) emission scenarios for the Island of, Barbados during the period of 2018 to2100 in Million Cubic Meters (MCM).

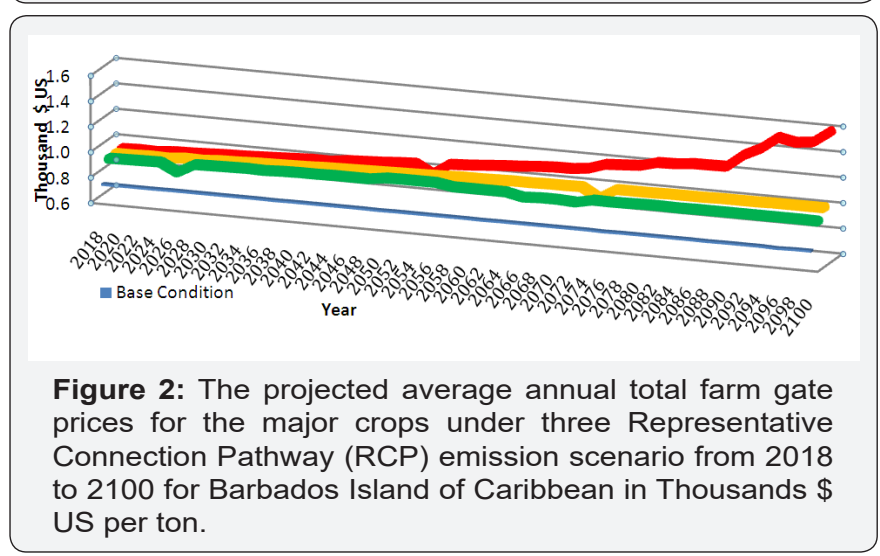

In other words, climate change will negatively impact the food consumers' security. Conversely, food producers would be able to tolerate those consequences as they would receive higher prices for their products, if they positively respond to the climate change by adopting modern irrigation technology. However, food producers' ability to adapt to the climate change will depend on the scale of their operations scale and the applicability of new irrigation technology. The investigation of interrelationship of water demand for irrigation with that of other sectors such as municipal use and environmental water uses is critical. Given the expected water scarcity brought on by climate change, different adaptation policies could be implemented to mitigate the negative impacts on different sectors.

However, adaptation measures if they target just specific sectors run the risk of creating unintended externalities. Hence there is a need for a holistic approach to the design and implementation of adaptation and mitigation policies for climate change. In this way the interrelated impacts can be more accurately evaluated. The efficiency and sustainability of adaptation and mitigation policies need to be investigated not only based on their physical impacts but also based on their socioeconomic impacts on water users' wellbeing. The integration of hydrologic models with socioeconomic models will be a critical improvement that requires further integration and development in the area of climate change and water 
resources management in order to achieve a better balance between societal needs and ecosystem functioning.

\section{References}

1. Gohar A, Cashman A (2016) A methodology to assess the impact of climate variability and change on water resources, food security and economic welfare. Agricultural Systems 147: 51-64.

2. Arnell NW, Lloyd-Hughes B (2014) The global-scale impacts of climate change on water resources and flooding under new climate and socioeconomic scenarios. Climatic Change 122: 127-140.

3. Chang SW, Nemec K, Kalin L, Clement TP (2016) Impacts of Climate Change and Urbanization on Groundwater Resources in a Barrier Island. Journal of Environmental Engineering 142(12).

4. Dams J, Salvadore T, Van Daele V, Ntegeka (2012) Spatio-temporal impact of climate change on the groundwater system. Hydrology and Earth System Sciences 16(5): 1517-1531.
5. Berg A N, Sultan B, Lengaigne M, Guimberteau M (2013) Projections of climate change impacts on potential C4 crop productivity over tropical regions. Agricultural and Forest Meteorology 170: 89-102.

6. Challinor AJ, Watson J, Howdan SM (2014) A meta-analysis of crop yield under climate change and adaptation. Nature Climate Change 4(4): 287-291.

7. Zhou Y, Zwahlen F, Wang YX (2010) Impact of climate change on irrigation requirements in terms of groundwater resources. Hydrogeology Journal 18(7): 1571-1582.

8. Buytaert W, De Bievre B (2012) Water for cities: The impact of climate change and demographic growth in the tropical Andes. Water Resources Research P. 48.

9. Cashman A, Nurse L, John C (2010) Climate Change in the Caribbean: The Water Management Implications. Journal of Environment \& Development 19(1): 42-67.

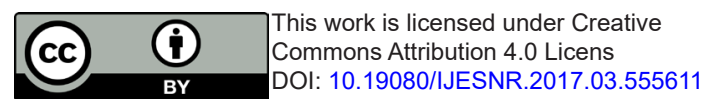

\section{Your next submission with Juniper Publishers will reach you the below assets}

- Quality Editorial service

- Swift Peer Review

- Reprints availability

- E-prints Service

- Manuscript Podcast for convenient understanding

- Global attainment for your research

- Manuscript accessibility in different formats ( Pdf, E-pub, Full Text, Audio)

- Unceasing customer service

Track the below URL for one-step submission https://juniperpublishers.com/online-submission.php 